\title{
EFEKTIVITAS PENGENALAN APLIKASI ZOOM MEETING PADA KARYAWAN DI INSTANSI PEMERINTAH DAERAH DI KECAMATAN BELITANG III OLEH MAHASISWA KKL/KKN UNIVERSITAS PGRI PALEMBANG
}

\author{
Bambang Hermansah ${ }^{1}$ Patricia. H.M. Lubis ${ }^{2}$ Dian Nuzulia Armariena ${ }^{3}$ \\ Universitas PGRI Palembang ${ }^{1,2,3}$ \\ bambanghermansah@univpgri-palembang.ac.id ${ }^{1}$
}

Saat masa pandemi COVID-19, setiap universitas di kantor instansi pemerintahan pusat dan Daerah melakukan sistem daring (dalam jaringan). Aplikasi yang banyak digunakan saat daring (dalam jaringan) ialah Zoom Meeting. Pengabdian ini dilakukan untuk mengetahui seberapa efektifnya penggunaan aplikasi Zoom Meeting terhadap para karyawan di instansi pemerintahan daerah Belitang III OKU Timur ketika pandemi COVID-19. Dengan skema KKL Program Kreativitas Mahasiswa (KKL/KKN), mahasiswa diharapkan dapat mengaktualisasikan kemampuannya untuk berkontribusi meningkatkan produktifitas. Model ini bersifat kualitatif grounded theory. Teknik pengumpulan data dilakukan dengan wawancara melalui Google Form dan Whatsapp kepada 14 belas mahasiswa Universitas PGRI Palembang yang melakukan Kuliah Kerja Lapangan. Hasil penelitian ini, menunjukkan bahwa penggunaan aplikasi Zoom Meeting tidak begitu efektif bagi para karyawan di instansi pemerintahan. Tetapi, aplikasi Zoom Meeting lebih baik karena dalam aplikasi Zoom Meeting komunikasi antara individu dilakukan secara lisan dibandingkan penggunaan aplikasi dalam jaringan yang melakukan kegiatan komunikasi secara tertulis menurut teori komunikasi pendidikan. Diharapkan bagi para karyawan di instansi pemerintahan kecamatan belitang III, selama pandemi dapat lebih efektif menggunakan aplikasi zoom meeting untuk rapat kerja dan koordinasi dengan instansi dari pusat dan bagi masyarakat siswa dapat belajar dirumah dengan tetap menjalankan protokol kesehatan hal ini dapat bermanfaat bagi siswa yang tidak ada gadget khususnya.

Kata kunci: Efektivitas, Aplikasi Zoom Meeting,Instansi Pemerintah

\section{Effectivenes Zoom Meeting Aplication in Goverment Belitang II From Student KKL/KKN PGRI Palembang University}

During the COVID-19 pandemic, every university in the central and local government agencies conducts an online system. An application that is widely used online is Zoom Meeting. This service was carried out to find out how effective the use of Zoom Meeting application. This research is qualitative and uses grounded theory method. Data collection techniques were conducted by interviewing through Google Form and Whatsapp to 14 students of PGRI Palembang University who conducted Field Work Lectures. The results of this study showed that the use of Zoom Meeting application is not very effective for employees in government agencies. However, Zoom Meeting 


\section{WAHANA DEDIKASI}

application is better because in Zoom Meeting application communication between individuals is done orally than the use of applications in the network that conduct communication activities in writing according to educational communication theory.It is expected that for employees in belitang III sub-district government agencies, during the pandemic can more effectively use zoom meeting applications for work meetings and coordination with institutions from the center and for the community students can study at home while still carrying out health protocols this can be useful for students who do not have gadgets in particular.

Key Words: Effectivenes, Zoom Aplication, Goverment Instantion

Artikel disetujui tanggal:08-09-2020

Corresponden Author:Ardo Okilanda e-mail:ardo.oku@mail.com

DOI: http://dx.doi.org/10.31851/dedikasi.v3i2.5262 do:

\section{PENDAHULUAN}

Undang-undang Tentang

Pendidikan Tinggi (Indonesia, 2012),

disebutkan bahwa pengabdian kepada

masyarakat merupakan kegiatan

sivitas akademika dalam

mengamalkan dan membudayakan

ilmu pengetahuan dan teknologi

untuk memajukan kesejahteraan

umum dan mencerdaskan kehidupan

bangsa. Program pengabdian kepada

masyarakat yang dilaksanakan oleh

Perguruan Tinggi (PT) adalah salah

satu dari implementasi Tridharma

Perguruan Tinggi (Hera, et al., 2018).

Program ini dilaksanakan

dalam berbagai bentuk misalnya:

pendidikan dan pelatihan masyarakat

(Ramadhani, \& Putri., 2019),

pelayanan masyarakat dan kaji tindak

dari Ilmu Pengetahuan dan Teknologi

(Iptek) yang dihasilkan oleh
Perguruan Tinggi. Tujuan program ini adalah menerapkan hasil-hasil Iptek untuk pemberdayaan masyarakat sehingga menghasilkan perubahan pengetahuan, keterampilan, dan sikap dari kelompok masyarakat sasaran (Noor, 2010).

$$
\text { Kuliah Kerja Lapangan }
$$

(KKL) merupakan salah satu bentuk kegiatan pengabdian masyarakat oleh mahasiswa dengan pendekatan lintas keilmuan dan sektoral pada waktu dan daerah tertentu. KKL merupakan kegiatan perkuliahan dan kerja lapangan yang merupakan pengintegrasian dari pendidikan dan pengajaran serta pengabdian kepada masyarakat oleh mahasiswa secara pragmatis, berdimensi luas melalui pendekatan interdisipliner, komprehensif dan lintas sektoral. 


\section{W/AHANA DEDIKASI}

KKL merupakan mata kuliah wajib pada seluruh program studi Sarjana dan Diploma di lingkungan Universitas PGRI Palembang. Inti dari mata kuliah KKL ini adalah pembelajaran sekaligus pengabdian pada masyarakat. Oleh karena itu, seluruh kegiatan yang mengandung nilai pembelajaran dan pengabdian pada masyarakat dapat diakui sebagai KKL.

Kuliah Kerja Lapangan (KKL) Merupakan kegiatan intrakurikuler yang dilakukan oleh mahasiswa Universitas PGRI Palembang secara langsung dilapangan untuk mempelajari bidang administrasi dan bidang lain yang relevan dengan program studi serta untuk menyumbang keterampilan dan ilmu pengetahuan yang dimiliki mahasiswa. Pelaksanaan KKL ini dengan melibatkan instansi pemerintah dan pemerintah. (Pedoman KKL/KKN: 2020).

Kuliah Kerja Nyata (KKN) merupakan salah satu bentuk pengabdian kepada masyarakat yang dilakukan oleh mahasiswa secara interdisipliner, institusional, dan kemitraan sebagai salah satu wujud dari tri dharma perguruan tinggi . KKN merupakan bentuk pendidikan melalui pengalaman belajar kepada mahasiswa secara langsung ditengahtengah masyarakat. Sasaran KKN dapat berupa Masyarakat lain yang dipandang layak menjadi Sasaran KKN. Sasaran KKN dapat berupa Masyarakat Pedesaan, Masyarakat perkotaan, sekolah, Masyarakat Industri, atau kelompok masyarakat lain yang dipandang layak menjadi sasaran KKN.

Mahasiswa berupaya untuk menjadi bagian dari Masyarakat serta secara akatif dan kreatif terlibat dalam Dinamika yang terjadi dimasyarakat. Keterlibatan mahasiswa bukan saja memberi pengaruh positif dan aktif terhadap pengembangan masyarakat, sehingga member warna baru dalam pembangunan masyarakat secara positif (Pedoman KKL/KKN: 2020;01).

KKN/KKL secara umum bertujuan untuk memandu mahasiswa menjadi pribadi yang baik (1) tahu dan taat aturan; (2) kreatif, inovatif dan (3) objektif kooperatif dalam 


\section{WAHANA DEDIKASI}

membangun keragaman intelektua.

Pada awalnya, dikenal lima jenis kegiatan yang ditawarkan dalam PKM, yaitu PKM- Penelitian (PKMP), PKM-Kewirausahaan (PKM- K), PKM-Pengabdian kepada Masyarakat (PKM-M), PKM-Penerapan Teknologi (PKM-T) dan PKMPenulisan Ilmiah (PKM-I) (Kemendikbud, 2020).

Berdasarkan hasil yang sudah didapatkan, kebanyakan mahasiswa melakukan kegiatan PKMKewirausahaan dengan tujuan untuk meningkatkan peran usaha kecil dan menengah di masyarakat. dapat dijadikan sebagai kegiatan usaha karena banyak dibutuhkan masyarakat pada saat ini. Kegiatan ini membuat masyarakat yang menekuninya menjadi tetap produktif dan dapat mengembangkan bidang usahanya.

Pada keadaan normal atau bukan pada masa pandemi seperti sekarang ini, maka pelaksanaan kegiatan KKL biasanya berlangsung antara satu sampai dua bulan dan bertempat di daerah setingkat desa. Beberapa contoh kegiatan KKL yang dapat dilakukan mahasiswa dalam keadaan normal yaitu: menjadi relawan di daerah yang terkena bencana alam, ikut serta dalam kegiatan kerja di puskesmas, ikut serta dalam Kegiatan Belajar Mengajar (KBM) di sekolah, mengenalkan pembuatan dan pengelolaan blog atau website resmi desa dan lain sebagainya.

KKM 2020 diikuti oleh sekitar 14 mahasiswa yang dibagi menjadi Empat daerah. Setiap kelompok dibagi lagi menjadi 3 sub kelompok yang masing-masing sub kelompok akan menghasilkan satu tuisan berupa proposal mengenai hasil KKL yang mereka lakukan. Kebetulan penulis membimbing Kelompok 14 yang terdiri dari sub kelompok 74.A, 74.B dan 74.C. Pada masa pandemi covid19 sekarang ini, kegiatan KKL berbeda dari tahun-tahun sebelumnya. Mahasiswa dibatasi untuk berkumpul baik dengan anggota kelompoknya apalagi untuk terjun secara langsung ke masyarakat.

Hal ini dimaksudkan untuk mencegah terjadinya penularan infeksi covid-19 yang sudah banyak 


\section{W/AHANA DEDIKASI}

memakan korban jiwa. Oleh karena itu, pihak manajemen dan akademik Universitas PGRI Palembang mengambil kebijakan bahwa KKL pada tahun 2020 tetap dilaksanakan tetapi dengan cara yang berbeda yaitu mahasiswa diminta untuk melakukan beberapa kegiatan sehingga menghasilkan luaran berupa dokumentasi yang dilaporkan ke universitas PGRI Palembang ke beberapa media sosial seperti youtube, facebook dan instagram. Selain itu mahasiswa dapat membuat artikel yang diterbitkan di media cetak baik lokal maupun nasional.

Sesuai dengan luaran yang ditargetkan yaitu mengunggah video di media sosial dan menulis artikel di media cetak, maka diharapkan kegiatan KKL 2020 ini. Zoom Meeting sendiri merupakan sebuah media pembelajaran, Rapat kerja dan lain sebagainya menggunakan video. Pendiri aplikasi Zoom Meeting yaitu Eric Yuan yang diresmikan tahun 2011 yang kantor pusatnya berada di San Jose, California.

Aplikasi ini tidak hanya digunakan untuk pembelajaran saja tetapi bisa digunakan untuk urusan perkantoran maupun urusan lainnya. Platfrom ini gratis jadi dapat digunakan oleh siapapun dengan batas waktu empat puluh menit dan tidak ada batasan waktu jika akun kita berbayar. Dalam aplikasi Zoom Meeting ini kita bisa berkomunikasi langsung dengan siapapun lewat video. Oleh karena itu, memang cocok digunakan sebagai media pembelajaran.

Penelitian ini bertujuan untuk mengetahui seberapa besar pemanfaatan Zoom Meeting sebagai media pembelajaran dan rapat kerja dalam jaringan di masa social distancing terhadap mahasiswa, karyawan di instansi pemerintah yang sedang menjalani pendidikan ataupun aktivitas pekerjaan. Dalam kegiatan pembelajaran/rapat kerja online dengan memanfaatkan penggunaan aplikasi Zoom Meeting, terdapat dua buah teori yang dapat meninjau kegiatan pembelajaran tersebut.

Teori behavioristik merupakan salah satu teori yang membahas tentang berubahnya perilaku seseorang yang didasari dari sebuah 


\section{W/AHANA DEDIKASI}

pengalaman. Teori behavioristik menekankan terbentuknya perilaku yang terlihat dari hasil proses belajar. Lalu, terdapat juga teori kognitif. Di dalam sebuah teori kognitif, tingkah laku individu dapat diarahkan melalui sudut pandang individu tersebut dan juga pengalamannya dalam situasi yang memiliki relasi dengan sebuah tujuan. Karena, dalam tingkah laku individu sifatnya dinamis. Sifat dinamis tersebutlah yang dipengaruhi oleh proses belajar .

Teori komunikasi pendidikan ataupun aktivitas pekerjaan juga menjadi sebuah landasan dalam penelitian ini. Karena dalam proses pembelajaran serta rapat kerja tentunya melakukan proses komunikasi. Komunikasi yang dilakukan mahasiswa dengan dosen atau mahasiswa dengan mahasiswa lainnya, pimpinan dengan bawahannya. Dalam penelitian ini, apakah pemanfaatan aplikasi Zoom Meeting oleh mahasiswa diuniversitas PGRI Palembang dan instansi pemerintah kecamatan belitang III dinilai cukup baik dalam proses komunikasi atau tidak.
Manfaat dilakukan penelitian ini ialah untuk mengetahui dampak dan tanggapan setiap mahasiswa yang sedang menjalani pendidikan di Universitas PGRI Palembang dan Instansi Pemerintah kecamatan Belitang III terhadap Rapat kerja dalam jaringan secara online jarak jauh menggunakan aplikasi Zoom Meeting.

Penelitian ini bermanfaat juga untuk menemukan sebuah solusi terhadap pemanfaatan aplikasi TIK yang diterapkan oleh pihak mahasiswa Universitas PGRI Palembang terhadap para karyawan di instansi Pemerintahan di Kecamatan Belitang III Oku Timur. supaya pembelajaran jarak jauh/ Rapat kerja online menggunakan aplikasi yang berbasis TIK, dapat optimal sehingga para karyawan di instansi Pemerintah Kecamatan Belitang III Oku Timur dan mahahasiswa Universitas PGRI Palembang tersebut tetap mendapatkan keuntungan dalam proses dalam jaringan atau online di tengah masa pandemi COVID-19.

Penelitian ini dilaksanakan pada tahun 2020. Metode penelitian 


\section{W/AHANA DEDIKASI}

yang kami lakukan merupakan Rancangan penelitian dilakukan metode penelitian kualitatif. melalui beberapa tahap yaitu: (1) Penelitian kualitatif didefinisikan membuat beberapa pertanyaan yang sebagai suatu pendekatan atau akan diajukan kepada Mahasiswa dan penelusuran untuk meng- eksplorasi dan memahami suatu gejala sentral (Sugiyono, 2013). Teknik pengambilan data yang kami lakukan ialah menggunakan google form. Kami menggunakan google form ini dikarenakan google form lebih cepat dan luas untuk menyebarkan kuesioner kepada subjek, di sisi lain karena adanya kebijakan social distancing ini maka tidak memungkinkan jika kami menggunakan metode wawancara secara langsung. Subjek penelitian ialah Karyawan Instansi pemerintah kecamatan Belitang III Oku Timur.

Mahasiswa dengan domisili wilayah Belitang III.

\section{BAHAN DAN METODE}

Penelitian ini dilaksanakan untuk mengetahui seberapa besar pemanfaatan platform Zoom Meeting oleh Mahasiswa KKN/KKL dan kayawan di instansi pemerintah Kecamatan Belitang III Oku Timur saat masa pandemi COVID-19. Karyawan melalui google form, (2) menyebarkan pertanyaan secara online melalui sosial media berupa WhatsApp, (3) mengumpulkan dan menyaring data yang sudah diisi oleh mahasiswa dan karyawan di instansi pemerintah Kecamatang Belitang III Oku Timur untuk kemudian dianalisis.

Teknik analisis data pada penelitian ini, menggunakan teknik analisis kualitatif dengan melakukan metode grounded theory (4). Proses dengan menggunakan grounded theory ini dilakukan dengan pengkodean dan pengkategorian data terhadap fenomena penggunaan aplikasi Zoom Meeting oleh para mahasiswa universitas PGRI Palembang dan Karyawan Instansi Pemerintah Kecamatan Blitang III Oku Timur di saat rapat kerja dalam jaringan (secara online) selama masa pandemi COVID-19.

$$
\text { Pada analisis data }
$$

menggunakan grounded theory, 


\section{WAHANA DEDIKASI}

diawali dengan proses open coding yang dimana melakukan identifikasi terhadap fenomena penggunaan aplikasi Zoom Meeting oleh para mahasiswa di Universitas PGRI Palembang

$$
\text { Lalu setelah tahap open }
$$
coding, dilanjutan dengan tahap axial coding yang dimana pada tahap axial coding menyatukan data mahasiswa Universitas PGRI Palembang dan Karyawan di instansi pemerintah kecamatan belitang III Oku Timur disaat rapat kerja dalam jaringan (secara online) selama masa pandemi COVID-19.

\section{Pada akhir dilakukannya} selective coding. Selective coding bertujuan untuk menyeleksi kategorisasi inti dan menyambungkan kategori lain pada penggunaan aplikasi Zoom Meeting oleh para mahasiswa di universitas PGRI Palembang dan karyawan Instansi pemerintah kecamatan Belitang III Oku Timur disaat rapat kerja dalam jaringan (secara online) selama masa pandemi COVID- 19.

\section{HASIL DAN PEMBAHASAN}

Penelitian ini dilakukan terhadap 14 (dua belas) mahasiswa yang sedang menjalani pendidikan di Universitas PGRI Palembang 14 (Dua belas) mahasiswa yang sedang menjalani pendidikan di Universitas Universitas PGRI Palembang antara lain ialah berasal dari kecamatan Belitang II, Belitang III, Belitang madang Raya, belitang Mulya yang terdapat pada tabel berikut:

Gambar 1. Tempat tinggal Asal mahasiswa

Sebelum adanya COVID-19 kegiatan rapat berjalan secara konvensional. Di setiap Instansi Pemerintahan Kecamatan Belitang III Oku Timur. Namun semenjak diberlakukannya social distancing mereka tidak lagi bisa melaksanakan praktik seperti biasanya. Begitupun karyawan di instansi pemerintah kecamatan Belitang III Oku Timur, Mereka sekarang beralih ke perkuliahan berbasis online atau $e$ learning dan kebanyakan dari mereka 


\section{W/AHANA DEDIKASI}

menggunakan aplikasi Zoom Meeting sebagai media untuk pembelajaran.

Dari ke empat belas mahasiswa yang sedang menjalani pendidikan di Universitas PGRI Palembang dan karyawan di instansi kecamatan belitang III Oku Timur, semua karyawan di instansi kecamatan belitang III Oku Timur tersebut baru pertama kali memakai Zoom Meeting untuk melakukan rapat berbasis online. Para karyawan di instansi kecamatan belitang III Oku Timur yang sedang menjalani pendidikan di Universitas wilayah Jakarta dan Depok sebelumnya menggunakan media pembelajaran berbasis online seperti Google Classroom, E-Learning universitas, dan Microsoft Teams.

\section{Fenomena}

penggunaan

aplikasi Zoom Meeting di kalangan mahasiswa yang sedang menjalani pendidikan di Universitas wilayah Jakarta dan Depok, dimulai saat terjadinya wabah pandemi COVID-19 yang mengaharuskan para mahasiswanya melakukan pembelajaran jarak jauh. Tetapi, menurut hasil penelitian yang kami peroleh, penggunaan aplikasi Zoom Meeting dalam media pembelajaran jarak jauh dinilai tidak begitu efektif untuk para mahasiswa yang sedang menempuh studi di Universitas Jakarta dan Depok.

Tabel 1. Karyawan pengguna Zoom

Meeting

\begin{tabular}{|l|l|}
\hline Mahasiswa & Total Persentase \\
\hline Pernah & $20 \%$ \\
\hline Tidak Pernah & $80 \%$ \\
\hline
\end{tabular}

Universitas PGRI Palembang untuk kegiatan KKL 2020 adalah "Merajut Asa Membangun Daerah" (Pedoman KKL/KKN: 2020;02).. Setiap mahasiswa diminta untuk membuat video atau artikel yang berkatian dengan tema tersebut, misalnya bagaimana menaati protokol kesehatan yang ditetapkan pemerintah untuk dapat tetap beraktifitas dan produktif di masa pandemi, bagaimana mengaplikasikan IT seperti Penggunaan Aplikasi Zoom Meeting, Google Meet Absensi menggunakan Google Form dan lain sebagainya sehingga dapat dimanfaatkan karayawan dan masyarakat untuk menghindari matarantai covid 19 serta sarana olahraga dan kegiatan rutin senam dapat meningkatkan daya tahan (imunitas) tubuh. Selain dari contoh itu, mahasiswa juga dapat mengunggah video 


\section{WAHANA DEDIKASI}

berolah raga untuk meningkatkan imunitas tubuh dari serangan berbagai macam penyakit.

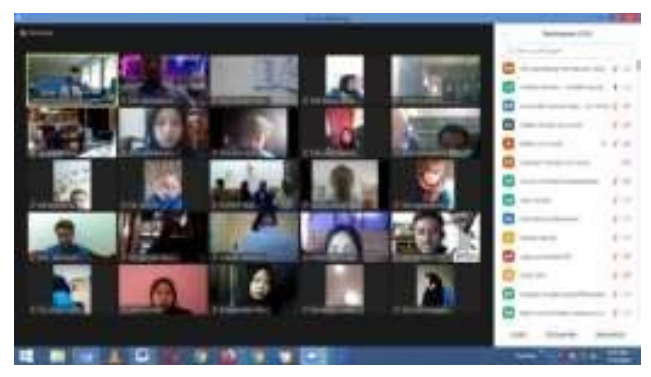

Gambar 2. Pembekalan KKL oleh

Dosen Pembimbing (di Kantor camat belitan III)

Dokumentasi tersebut ke beberapa media sosial, maka masyarakat luas dapat mengaksesnya dan mengambil manfaat dari video. Dapat dikatakan mahasiswa membagi pengetahuan yang mereka miliki kepada masyarakat, yang bagi penulis dapat disebut sebagai bagian dari kegiatan dalam melakukan pengabdian kepada masyarakat. Dari sejumlah video yang diunggah mahasiswa ke beberapa media sosial sebagai bagian dari Program Kerja Mahasiswa KKL/KKN, maka pada artikel ini penulis akan membahas 3 hal yang dilakukan oleh mahasiswa yaitu:

1. Pembuatan Lapangan sarana prasarana olahraga dan dan pembagian masker .

2. Membuat area bimbel bagi anak-anak dan ibu-ibu sebagai PKK.

3. Memperkenalkan aplikasi ZOOM Meeting sebagai sarana komunikasi di era covid-19 (mengenalkan kecanggihan teknologi sebagai sarana kewirausahaan)

Kegiatan dalam pembuatan lapangan bola voli sebagai sarana masyarakat untuk tetap melakukan olahragaa, seperti senam lansia dan pembagian masker ini merupakan kegiatan yang dilakukan oleh sub kelompok dalam Kelompok 74 di daerah belitang III Oku Timur.

Hasil sejumlah kegiatan tersebut, terbentuk sejumlah tujuan yang dapat meningkatkan produktifitas masyarakat yang positif. Selain itu, program kerja yang dibuat oleh mahasiswa seperti pembagian masker, pembuatan sarana olahraga, membuat area bimbel dapat meningkatkan ilmu pengetahuan bagi masyarakat di tengah pandemi covid19 seperti sekarang ini. Berikut 


\section{WAHANA DEDIKASI}

dijelaskan beberapa hal yang menjadi tujuan positif dari sejumlah kegiatan mahasiswa KKL:

(1) Memberikan masker secara Gratis Kemasyarakat.

(2) Membuat tempat belajar (mengaji) bagi anak- anak dikecamatan belitang III

(3) Meningkatkan peran kesadaran tetap menggunakan masker, mencuci tangan dan jaga jarak khususnya meningkatkan kesehatan masyarakat melalui olahraga di tengah pandemi covid-19.

(4) Membuat lapangan bola Voli.

(5) Melakukan Bhakti Sosial Memberihkan dan menanam bibit pohon.

(6) membuat schedule monitoring dengan dosen pembimbing melalui Aplikasi ZOOM Meeting dengan mentor kecamatan belitang.

(7) Memberikan pengetahuan cara mengaplikasikan Zoom Meetin ke Pihak instansi Pemerintah kecamatan Belitang III.
Walaupun pada kegiatan ini dilarang untuk terjun secara langsung ke masyarakat (seperti layaknya keadaan normal), akan tetapi kebijakan masih memperbolehkan mahasiswa untuk bertemu masyarakat dalam jumlah terbatas. Disarankan untuk melakukan kegiatan di lingkungan tempat tinggal mahasiswa dengan tetap memperhatikan dan menaati protokol kesehatan. Tabel berikut menjelaskan tentang realisasi kegiatan mahasiswa yang memuat informasi tentang produk yang dihasilkan, tempat dan jadwal pembuatan.

\section{KESIMPULAN}

Kesimpulan kegiatan KKL 2020 adalah sebagai berikut:

1. Pelaksanaan KKL 2020 memberikan kesempatan kepada mahasiswa untuk dapat membagikan pengetahuan mereka kepada masyarakat luas dalam hal membuat produk yang dapat bermanfaat bagi perlindungan tubuh di masa pandemi covid-19.

2. Kegiatan KKL 2020 dapat memberikan kontribusi yang lebih luas lagi kepada masyarakat dalam 


\section{WAHANA DEDIKASI}

hal meningkatkan Pelatihan dan penyuluhan di bidang kecanggihan teknologi untuk upaya masyarakat dapat mengakses dan komunikasi serta memberikan feedback dikemudian hari sebagai generasi penerus. Hal ini sesuai dengan program yang ditetapkan panitia KKL Universitas PGRI Palembang yaitu dilaksanakan dengan skema KKL Program Kreativitas Mahasiswa (KKL).

3. Sesuai dengan tema KKL 2020, maka secara keseluruhan dapat disimpulkan bahwa kegiatan KKL 2020 mempunyai kontribusi untuk dapat meningkatkan produktifitas masyarakat di tengah covid-19.

\section{DAFTAR PUSTAKA}

Hera, T., Rochayati, R., Diah, N., Elvandari, E., \& Nurdin, N. (2018). Pelatihan tari lenggang patah sembilan dalam konteks pementasan tari pada siswa-siswi smp negeri $\quad 30 \quad$ kota palembang. Wahana dedikasi, 1(2).
Indonesia, R. (2012). UU RI Nomor 12 Tahun 2012 Tentang Pendidikan Tinggi. Kemendikbud. (2020). BukuPedoman-PKM-2020.

Pedoman KKN/KKL.2020 "Merajut Asa Membangun Daerah" Universitas PGRI Palembang. Palembang.

Ramadhani, E., \& Putri, R. D. (2019). Pelaksanaan konseling pada anak jalanan. Wahana dedikasi, 2(1).

Sukmayadi, A. E., Sumiwi, S. A., Barliana, M. I., \& Aryanti, A. D. (2014). The Immunomodulatory Activity of Ethanol Extract of Tempuyung Leaves (Sonchus arvensis Linn.). Indonesian Journal of Pharmaceutical Science and Technology, 1(2), 65-72. 